\title{
Pollination of Rapeseed (Brassica napus) by Africanized Honeybees (Hymenoptera: Apidae) on Two Sowing Dates
}

\author{
EMERSON D. CHAMBÓ ${ }^{1}$, NEWTON T.E. DE OLIVEIRA ${ }^{1}$, \\ REGINA C. GARCIA ${ }^{1}$, JOSÉ B. DUARTE-JÚNIOR ${ }^{1}$, \\ MARIA CLAUDIA C. RUVOLO-TAKASUSUKI ${ }^{2}$ and VAGNER A. TOLEDO ${ }^{3}$ \\ ${ }^{1}$ Universidade Estadual do Oeste do Paraná, Campus Universitário de Marechal Cândido Rondon, \\ Centro de Ciências Agrárias, Rua Pernambuco, 1777, 85960-000 Marechal Cândido Rondon, PR, Brasil \\ ${ }^{2}$ Universidade Estadual de Maringá, Centro de Ciências Biológicas, Departamento de Biotecnologia, \\ Genética e Biologia Celular, Av. Colombo, 5790, Jardim Universitário, 87020-900 Maringá, PR, Brasil \\ ${ }^{3}$ Programa de Pós-Graduação em Zootecnia, Universidade Estadual de Maringá, Centro de Ciências Agrárias, \\ Av. Colombo, 5790, Bloco J45, Campus Universitário 87020-900 Maringá, PR, Brasil
}

Manuscript received on January 21, 2014; accepted for publication on June 23, 2014

\begin{abstract}
In this study, performed in the western part of the state of Paraná, Brazil, two self-fertile hybrid commercial rapeseed genotypes were evaluated for yield components and physiological quality using three pollination tests and spanning two sowing dates. The treatments consisted of combinations of two rapeseed genotypes (Hyola 61 and Hyola 433), three pollination tests (uncovered area, covered area without insects and covered area containing a single colony of Africanized Apis mellifera honeybees) and two sowing dates (May 25th, 2011 and June 25th, 2011). The presence of Africanized honeybees during flowering time increased the productivity of the rapeseed. Losses in the productivity of the hybrids caused by weather conditions unfavorable for rapeseed development were mitigated through cross-pollination performed by the Africanized honeybees. Weather conditions may limit the foraging activity of Africanized honeybees, causing decreased cross-pollination by potential pollinators, especially the Africanized A. mellifera honeybee. The rapeseed hybrids respond differently depending on the sowing date, and the short-cycle Hyola 433 hybrid is the most suitable hybrid for sowing under less favorable weather conditions.
\end{abstract}

Key words: Apis mellifera, Brassicaceae, climatic conditions, pollinators.

\section{INTRODUCTION}

Rapeseed (Brassica napus L. var. oleifera Metzger) is an important oilseed crop in Brazil; however, the average yield of $1,226 \mathrm{~kg} \mathrm{ha}^{-1}$ (CONAB 2012) is much lower than that of the world average of $1,820 \mathrm{~kg} \mathrm{ha}^{-1}$ (USDA 2012). The introduction of Apis mellifera L.

Correspondence to: Vagner Arnaut Toledo

E-mail: abelha.vagner@gmail.com honeybee colonies to rapeseed crops may increase production rates (Abrol and Shankar 2012).

Although rapeseed is considered a predominantly self-pollinating and self-compatible plant (Hoyle et al. 2007, OGTR 2011, Abrol 2012), the contribution of honeybees to the pollination of this species has resulted in a significant increase in grain yield (Williams et al. 1987, Morandin and 
Winston 2005, Sabbahi et al. 2005, Abrol 2007, Araneda-Durán et al. 2010, Pierre et al. 2010, Rosa et al. 2011).

The rate of cross-pollination in rapeseed varies with the diversity of pollinating insects, cultivar and climatic conditions (CFIA 1999). The efficiency of self-pollination and cross-pollination processes that lead to grain production is dependent on factors related to the reproductive mechanisms of the plant (protogyny or protandry) and on environmental conditions. In Sweden, for example, a study of crosspollination rates in the B. napus cultivar "Topa" at different locations, indicated a variation of $12 \%$ to $47 \%$ in cross-pollination rates, demonstrated by isoenzyme analysis (Becker et al. 1992).

The most favorable regions for rapeseed cultivation are those that exhibit an average temperature of $20^{\circ} \mathrm{C}$ during the plant cycle (Thomas 2003). Temperatures higher than $27^{\circ} \mathrm{C}$ may result in floral sterility and the subsequent loss of grain yield (Morrison and Stewart 2002). In addition, high temperatures during pre-anthesis may cause pollen sterility and can retard the growth of the pollen tube during anthesis (Prasad et al. 2001).

Climatic factors can also act indirectly on rapeseed grain production by limiting insect activity during the collection of floral resources. Lower flower foraging activity by pollinators can result in lower pollen removal from the anthers and, therefore, less pollen deposition on the stigma, which limits the effect of cross-pollination by the insects (Thomson and Goodell 2002, Wilcock and Neiland 2002). Africanized honeybees exhibit optimal temperature and relative humidity ranges for the collection of nectar and pollen (MalerboSouza and Silva 2011).

An understanding of the possible interactions between ecological and environmental factors that might influence yield and seed quality components in rapeseed are of great importance for obtaining the maximum productive potential in rapeseed crops. In this study, possible interactions between pollination tests, rapeseed hybrids and sowing dates relative to production and seed quality variables were analyzed. The effects of environmental factors on yield and seed quality were investigated in rapeseed genotypes sown on two different dates.

\section{MATERIALS AND METHODS}

The experiment was performed on the rapeseed (Brassica napus L. var. oleifera) crop during the 2011 harvest season at the Experimental Station at the State University of West Paraná (Universidade Estadual do Oeste do Paraná, Unioeste), which is located in the municipality of Marechal Cândido Rondon (state of Paraná, Brazil; 24³2'09"S and $54^{\circ} 01^{\prime} 11^{\prime \prime} \mathrm{W} ; 392$ meters above sea level).

The soil at the experimental area was classified as Eutrudox Red Latosol (Embrapa 2006). Crambe (Crambe abyssinica), quinoa (Chenopodium quinoa), corn (Zea mays) and B. napus crops were growing near the experimental area, and an apiary containing six colonies of Africanized honeybees was located at a distance of approximately $1 \mathrm{~km}$.

The rapeseed hybrids used in this experiment were medium-cycle Hyola 61, characterized by a broad adaptation to the different environmental conditions characteristic to Brazil, and short-cycle Hyola 433, which exhibits a high requirement for favorable environmental factors, especially high soil fertility (Tomm et al. 2009).

Environmental conditions data were collected and were recorded during the experiment at the Experimental Weather Station of the Unioeste and are shown in Fig. 1.

The experimental design was a randomized complete block with a $3 \times 2 \times 2$ factorial scheme and four replications. The treatments entailed a combination of the following: three pollination tests (demarcated area free to insect visitation control; area covered with a pollination cage and containing an A. mellifera colony - area visited only by Africanized honeybees; and area covered 


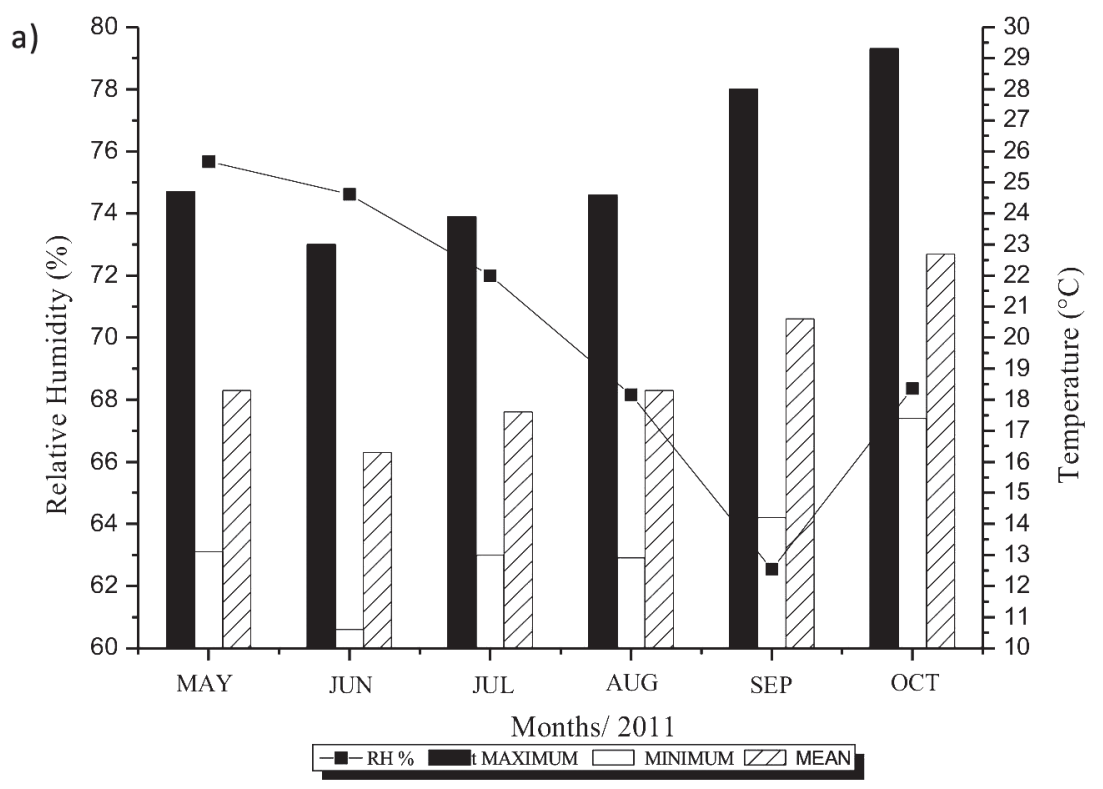

b)

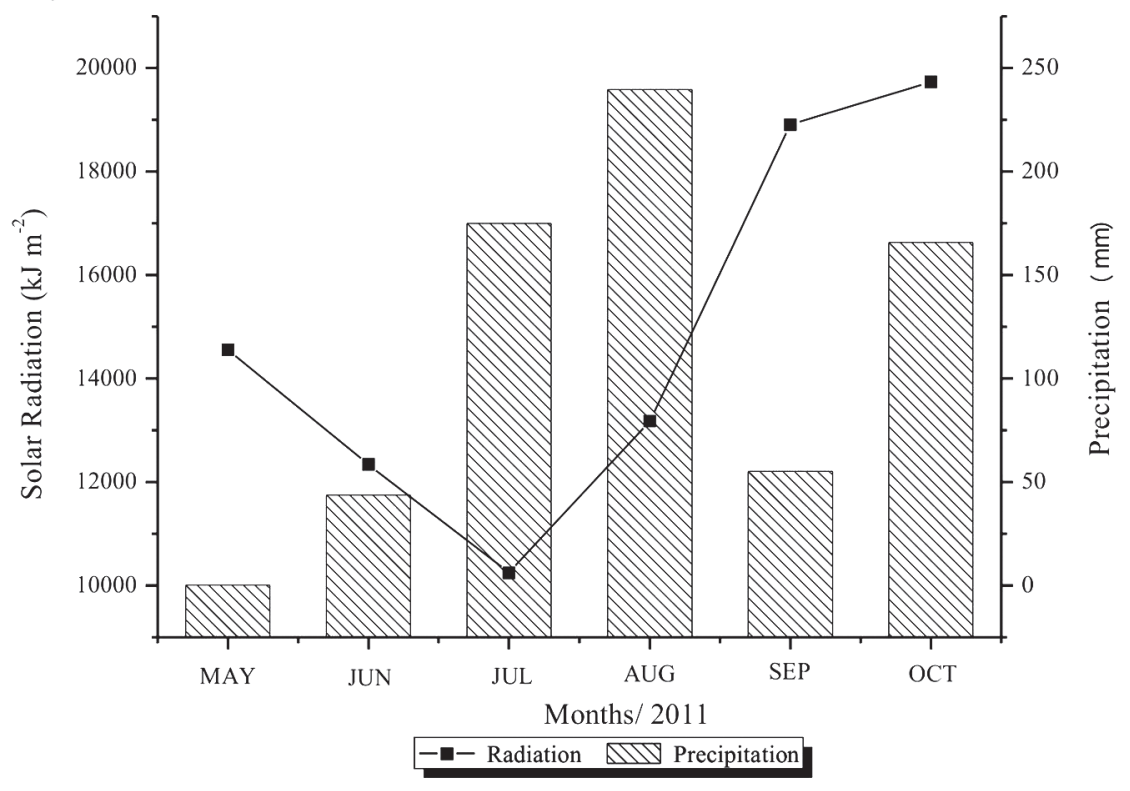

Fig. 1 - Environmental conditions for the period May-October 2011 in the experimental area at the municipality of Marechal Cândido Rondon (state of Paraná, Brazil). (a) RH (\%) - relative humidity, maximum, minimum and mean temperature $\left({ }^{\circ} \mathrm{C}\right)$. (b) Rainfall $(\mathrm{mm})$ and solar radiation $\left(\mathrm{kJ} \cdot \mathrm{m}^{2}\right)$.

with a pollination cage without honeybees - area of total insect exclusion), two sowing dates (May 25th, 2011 and June 25th, 2011) and two rapeseed hybrids (Hyola 61 and Hyola 433).

The experimental area measured $90 \mathrm{~m}$ long $\mathrm{x}$ $21 \mathrm{~m}$ wide (representing a seeded area of $1.512 \mathrm{~m}^{2}$ ).
The rapeseed hybrids were sown using a direct (no-till) planting system. Corn was grown in the intercrop period. The 12-15-15 NPK fertilizer (200 $\mathrm{kg} \mathrm{ha}^{-1}$ ) was used for the base dressing.

The hybrids were sown on May 25th, 2011 and June 25th, 2011 in 48 plots, each measuring $24 \mathrm{~m}^{2}$. 
In each plot, the plants were sown in eight rows spaced $0.45 \mathrm{~m}$ apart, with a $0.05-\mathrm{m}$ space between each plant. The sowing depth was $0.01 \mathrm{~m}$. At the two-to-four true leaf stage, thinning was performed to obtain a uniform density of 40 plants $\mathrm{m}^{-2}$ in the plots. At the phenological stage (four developed leaves), $30 \mathrm{~kg}$ of $\mathrm{N} \mathrm{ha}^{-1}$ in the form of ammonium sulfate were applied as a top dressing in accordance with technical guidelines for growing rapeseed (Tomm et al. 2009).

Pollination cages were constructed using a $2 \mathrm{x}$ 2-mm nylon mesh supported by $3 / 4$-inch PVC tubes, which formed cages measuring $4 \mathrm{~m}$ wide, $6 \mathrm{~m}$ long and $2 \mathrm{~m}$ high at the tallest point, and encompassed a $24 \mathrm{~m}^{2}$ area (Chiari et al. 2005) (Fig. 2).

The cages were assembled $5 \mathrm{~d}$ before flowering and were disassembled at the end of the flowering period to allow complete plant development. At the onset of flowering, the plots caged with honeybees received a colony of Africanized A. mellifera consisting of five frames, three containing the brood and two containing the food. Throughout flowering, the individual colonies were supplied with drinking water and a food supplement consisting of 0.5 liter of syrup containing approximately 50\% sugar (Free 1993).

For the May 25th, 2011 sowing date, flowering began on July 24th, 2011 and July 31st, 2011 and lasted until August 25th, 2011 and September 1st, 2011 for the rapeseed hybrids Hyola 433 and Hyola 61, respectively. For the June 25th, 2011 sowing date, flowering began on August 26th, 2011 and September 3rd, 2011 and lasted until September 27th, 2011 and October 4th, 2011 for the Hyola 433 and Hyola 61 genotypes, respectively.

The harvest was performed manually after the onset of pod dehiscence. The hybrids Hyola 433 and

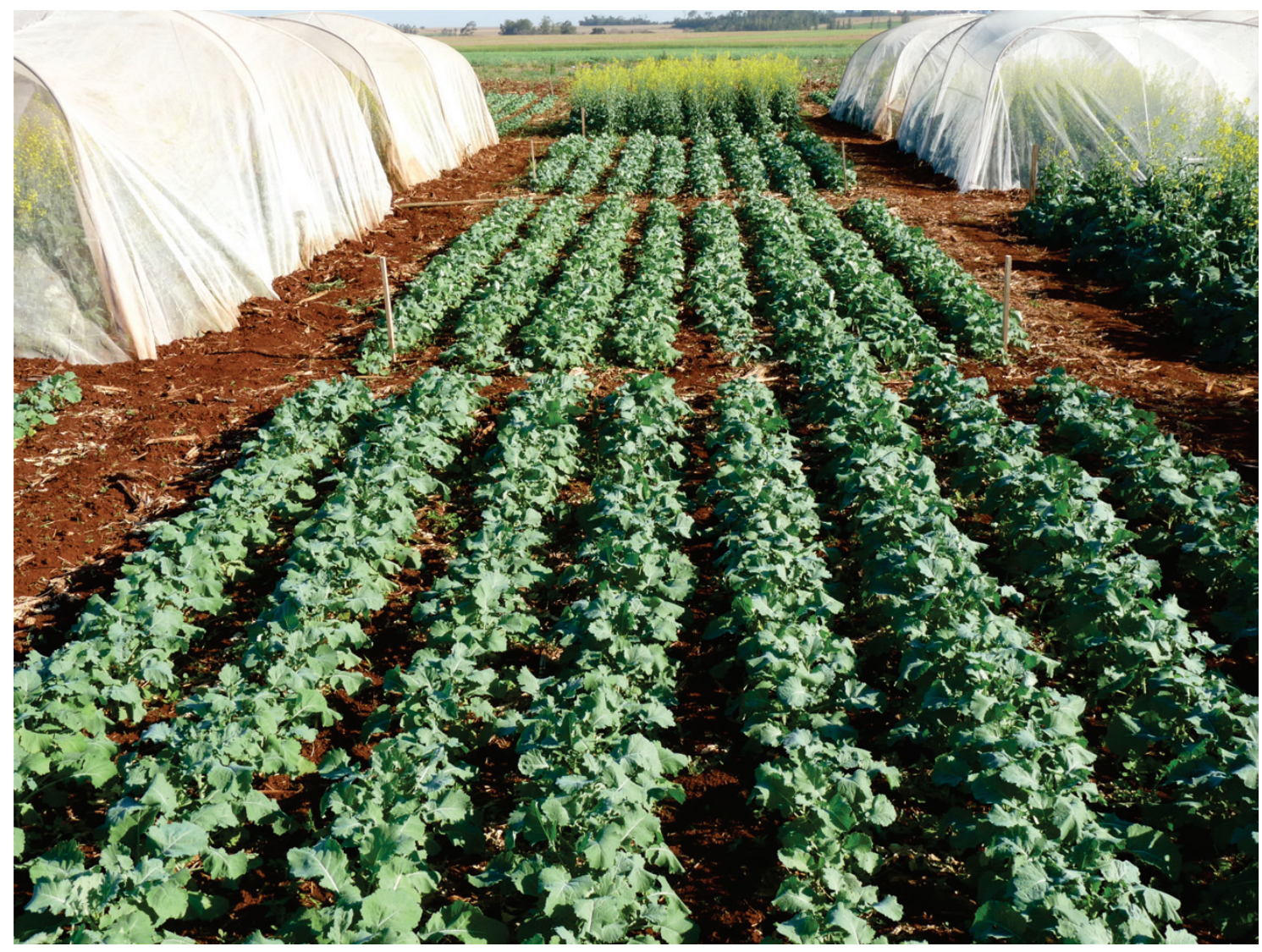

Fig. 2 - Experimental area with pollination cages. 
Hyola 61 sown on May 25th, 2011 were harvested at 123 (September 28th, 2011) and $132 \mathrm{~d}$ (October 7th, 2011), respectively. For the hybrids Hyola 433 and Hyola 61 sown on June 25th, 2011, the harvest was performed at 118 (October 23th, 2011) and 124 d (November 1st, 2011), respectively.

Grain yield (GY, kg ha ${ }^{-1}$ ) was estimated after cleaning, classification and weighing of the grains harvested from the four central meters of the two plant rows located at the center of each plot, representing a total area of $3.6 \mathrm{~m}^{2}$. The GY was corrected to $10 \%$ moisture, which is the reference percentage moisture used commercially and indicated for short-term storage (Tomm et al. 2009). Seed moisture content was determined in two replicates of each experimental unit using the oven method at $105{ }^{\circ} \mathrm{C} \pm 30{ }^{\circ} \mathrm{C}$ for $24 \mathrm{~h}$ (Brasil 2009).

To measure the grain mass per plant and to estimate the grain components, 10 plants were harvested at random from each plot, and the mean values of the following variables were calculated: a) grain mass per plant (GMPl, in g plant ${ }^{-1}$ ), obtained by individually weighing the grains from each plant; b) number of pods per plant (NPP, in units), obtained by counting the pods from 10 plants per treatment; and c) number of grains per pod (NGP, in units), obtained by randomly collecting 20 pods per treatment.

Calculations of the mass of 1,000 grains (MTG, in g), vigor (VG) and germination (GER) were based on the Rules for Seed Analysis (Brasil 2009). The ether extract content was quantified by the "hot" extraction method (two replicates per treatment) using the Soxhlet extractor, and petroleum ether ( $\mathrm{pa}$ ) was used as the solvent.

The data were subjected to analysis of variance in a triple factorial scheme. The Student-NewmanKeuls test was used to compare the means of the variables analyzed among the classes of the pollination test factor. The effects of hybrid and sowing date on the response variables were tested using the $F$-test. A 5\% probability level was adopted in both analyses. Statistical analyses were performed using the Statistical Analysis System (SAS, SAS Institute 2012) software.

\section{RESULTS}

A summary of the analysis of variance of probability values $(P)$ related to the sources of variation included in the statistical model is shown in Table I.

The GMPl and the grain mass per pod (GMPd) were affected significantly by the triple interaction among the hybrid, sowing date and pollination tests (Table 1). The GMP1 value for the uncovered area did not differ from the area covered by cages with honeybees, and both were greater than the GMPl values for the area covered by cages without insects for both hybrids sown on May 25th, 2011 (pollination/sowing date-1: Hyola 61: $F=24.07, \mathrm{df}=2, P=0.0002 ;$ pollination/sowing date-1: Hyola 433: $F=14.54, \mathrm{df}=2, P=0.0015$ ) (Table II).

There was no difference in the GMP1 among pollination tests for the Hyola 61 hybrid sown on June 25th, 2011 (pollination/sowing date-2: Hyola 61: $F=0.73, \mathrm{df}=2, P=0.6283)$. The GMPl was greater in the uncovered area compared to the covered areas with honeybees and without insects and did not differ for the Hyola 433 hybrid sown on June 25th, 2011 (pollination/sowing date-2: Hyola 433: $F=11.28, \mathrm{df}=2, P=0.003$ ) (Table II).

The GMPd value from the uncovered area and from the covered area with honeybees did not differ and was greater than the GMPd from the covered area without insects for both genotypes on both sowing dates, with the exception of the Hyola 433 hybrid sown on May 25th, 2011 (pollination/ sowing date-1: Hyola 61: $F=19.81$, df $=2, P=$ 0.0005 ; pollination/sowing date-1: Hyola 433: $F=1.74, \mathrm{df}=2, P=0.2297$; pollination/sowing date-2: Hyola 61: $F=10.41$, df $=2, P=0.0045$; pollination/sowing date-2: Hyola 433; $F=20.36$, $\mathrm{df}=2, P=0.0004)$ (Table II). 
TABLE I

Summary of the significance probability of the initial analysis of variance for each dependent variable.

\begin{tabular}{|c|c|c|c|c|c|c|c|}
\hline Variable & Hybrid & Sowing Date & Pollination & $\begin{array}{c}\text { Hybrid } \\
\text { x } \\
\text { Sowing Date }\end{array}$ & $\begin{array}{c}\text { Hybrid } \\
\text { x } \\
\text { Pollination }\end{array}$ & $\begin{array}{c}\text { Sowing Date } \\
\mathrm{x} \\
\text { Pollination }\end{array}$ & $\begin{array}{c}\text { Hybrid } \\
\mathrm{x} \\
\text { Sowing Date } \\
\mathrm{x} \\
\text { Pollination }\end{array}$ \\
\hline MGP1 & NS & $c$ & $c$ & $a$ & NS & $b$ & $a$ \\
\hline MGPd & NS & $c$ & $c$ & $c$ & NS & NS & $b$ \\
\hline NGP & $c$ & NS & $c$ & $c$ & NS & $b$ & NS \\
\hline GY & $b$ & $c$ & $c$ & NS & NS & $a$ & NS \\
\hline MTG & $a$ & $c$ & NS & $a$ & NS & $a$ & NS \\
\hline NPP & $c$ & $c$ & $a$ & $c$ & $a$ & NS & NS \\
\hline $\mathrm{OC}$ & b & $\mathrm{c}$ & NS & $a$ & NS & NS & NS \\
\hline VG & $a$ & $a$ & NS & $a$ & NS & NS & NS \\
\hline GER & $a$ & $a$ & NS & $a$ & NS & NS & NS \\
\hline
\end{tabular}

${ }^{a} P<0.05 ;{ }^{b} P<0.005 ;{ }^{c} P<0.0001$; NS - not significant. GMPl - grain mass per plant, GMPd - grain mass per pod, $\mathrm{NGP}$ - number of grains per pod, GY - grain yield, MTG - mass of 1,000 grains, NPP - number of pods per plant, OC - oil content, VG - vigor and GER - germination.

TABLE II

Mean and standard deviation values for grain mass per plant (GMPI) and grain mass per pod (GMPd) per pollination, hybrid and sowing date combination in Marechal Cândido Rondon (state of Paraná, Brazil).

\begin{tabular}{|c|c|c|c|c|c|}
\hline \multirow[b]{2}{*}{ Variable } & \multirow[b]{2}{*}{ Pollination } & \multicolumn{2}{|c|}{ Hyola 61} & \multicolumn{2}{|c|}{ Hyola 433} \\
\hline & & $\begin{array}{c}\text { Sowing Date } \\
05 / 25 / 2011\end{array}$ & $\begin{array}{c}\text { Sowing Date } \\
06 / 25 / 2011 \\
\end{array}$ & $\begin{array}{c}\text { Sowing Date } \\
05 / 25 / 2011\end{array}$ & $\begin{array}{c}\text { Sowing Date } \\
06 / 25 / 2011\end{array}$ \\
\hline \multirow{3}{*}{ GMP1 (g) } & Uncovered area & $18.57 \mathrm{Aa} \pm 2.96$ & $3.78 \mathrm{Ba} \pm 0.76$ & $17.73 \mathrm{Aa} \pm 1.24$ & $8.27 \mathrm{Ba} \pm 1.45$ \\
\hline & Covered area without insects & $11.88 \mathrm{Ab} \pm 2.40$ & $2.76 \mathrm{Ba} \pm 0.61$ & $12.63 \mathrm{Ab} \pm 2.16$ & $3.03 \mathrm{Bb} \pm 0.49$ \\
\hline & Covered area with honeybees & $19.05 \mathrm{Aa} \pm 2.47$ & $4.09 \mathrm{Ba} \pm 0.96$ & $18.28 \mathrm{Aa} \pm 1.14$ & $4.26 \mathrm{Bb} \pm 0.34$ \\
\hline \multirow{3}{*}{ GMPd (g) } & Uncovered area & $0.0628 \mathrm{Aa} \pm 0.0050$ & $0.0441 \mathrm{Ba} \pm 0.0050$ & $0.0658 \mathrm{Aa} \pm 0.0058$ & $0.0450 \mathrm{Ba} \pm 0.0049$ \\
\hline & Covered area without in & $0.0425 \mathrm{Ab} \pm 0.0083$ & $0.0351 \mathrm{Ab} \pm 0.0057$ & $0.0594 \mathrm{Aa} \pm 0.0051$ & $0.0245 \mathrm{Bb} \pm 0.0044$ \\
\hline & Covered area with honeybees & $0.0614 \mathrm{Aa} \pm 0.0007$ & $0.0515 \mathrm{Ba} \pm 0.0084$ & $0.0642 \mathrm{Aa} \pm 0.0071$ & $0.0436 \mathrm{Ba} \pm 0.0041$ \\
\hline
\end{tabular}

Means in the same column followed by different lowercase letters differ between pollination tests per each hybrid and sowing date combination according to the Student-Newman-Keuls test $(P<0.05)$. Means in the same row followed by different uppercase letters differ between sowing dates per each hybrid and pollination combination according to the $F$-test at the $5 \%$ significance level. The means were calculated from four observations.

In addition, the GMPI and GMPd values were greater for the rapeseed hybrids sown on May 25th, 2011 than on June 25th, 2011, with the exception of the Hyola 61 hybrid in the covered area without insects, which exhibited equivalent mean GMPd values between sowing dates (sowing date/cages without honeybees: Hyola $61: F=4.28, \mathrm{df}=1$, $P=0.08)$ (Table II).
There was no difference in GMPl between hybrids in each pollination test and on both sowing dates, with the exception of the Hyola 433 hybrid in the uncovered area sown on June 25th, 2011, which exhibited a higher GMPl compared with the Hyola 61 hybrid (hybrid/uncovered area: sowing date-1: $F=0.53$, df $=2, P=0.61$; hybrid/cage without insects: sowing date-1: $F=0.42$, df $=2, P=$ 
0.67 ; hybrid/cage with honeybees: sowing date-1: $F$ $=0.44, \mathrm{df}=2, P=0.66$; hybrid/uncovered area : sowing date- $2: F=15.11, \mathrm{df}=2, P=0.001$; hybrid/ cage without honeybees: sowing date- $2: F=0.06$, df $=2, P=0.94$; hybrid/cage with honeybees: sowing date-2: $F=0.02, \mathrm{df}=2, P=0.98$ ) (Fig. 3).

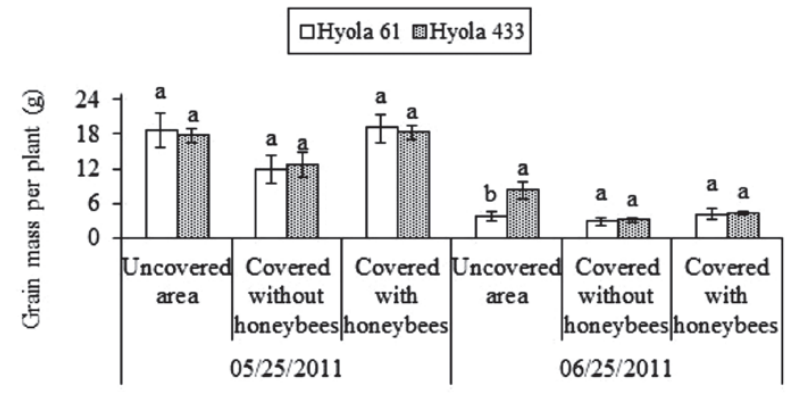

Fig. 3 - Grain mass per plant (g) of rapeseed hybrids in response to sowing dates and pollination tests. Different lowercase letters in each pollination test indicate significant differences according to the $F$-test $(P<0.05)$.

The NPG and GY did not differ between the uncovered area and the covered area with honeybees and was higher than in the covered area without insects on May 25th, 2011 (NGP-pollination: sowing date-1; $F=28.10$, df $=2, P<0.0001$; GYpollination: sowing date-1: $F=16.44$, df $=2$, $P<0.0001)$. The MTG did not differ between the covered areas with honeybees and the covered areas without insects; however, the MTG value in the covered area without insects was higher than in the uncovered area for the May 25th, 2011 sowing date (MTG-pollination: sowing date-1: $F=3.73$, $\mathrm{df}=2, P=0.0345)$ (Table III).

For sowing date June 25th, 2011, the NPG was greater in the covered area with honeybees compared to the uncovered area and to the covered area without insects, and the NPG was smaller in the covered area without insects compared to the uncovered area (NPG-pollination: sowing date-2: $F=59.79$, df $=2, P<0.0001)$. GY did not differ between the uncovered area and the covered area with honeybees and was higher than in the covered area without insects for sowing date June 25th, 2011 (GY-pollination: sowing date-2: $F=8.26, \mathrm{df}=2, P=$ 0.0012 ). There was no difference among pollination tests for the MTG between the genotypes sown on June 25th, 2011 (MTG-pollination: sowing date-2; $F$ $=0.68 ; \mathrm{df}=2 ; P=0.5112$ ) (Table III).

For each of the pollination tests, the GY and MTG were higher when sowing was performed on May 25th, 2011 than on June 25th, 2011, regardless of the hybrid tested (GY-sowing date: uncovered area, $F=86.43$, df $=1, P<0.0001$; cage without insects, $F=73.34$, df $=1, P<0.0001$; cage with honeybees, $F=138.87$, df $=1, P<0.0001$; MTGsowing date: uncovered area, $F=83.35, \mathrm{df}=1, P<$ 0.0001 ; cage without insects, $F=167.32, \mathrm{df}=1$,

TABLE III

Mean and standard deviation values for the number of grains per pod, grain yield and mass of 1,000 grains per pollination test and sowing date combination in Marechal Cândido Rondon (state of Paraná, Brazil).

\begin{tabular}{ccccc}
\hline \multirow{2}{*}{$\begin{array}{c}\text { Sowing } \\
\text { Date }\end{array}$} & Pollination Tests & \multicolumn{3}{c}{${\text { Variable }(\mathrm{mean} \pm \mathrm{SD})^{a}}$} \\
\cline { 3 - 5 } & & Number of Grains per Pod & Grain Yield $\left(\mathrm{kg} \mathrm{ha}^{-1}\right)$ & Mass of 1,000 Grains $(\mathrm{g})$ \\
\hline \multirow{2}{*}{$05 / 25 / 11$} & Uncovered area & $19.6 \mathrm{Aa} \pm 1.96$ & $1,778.46 \mathrm{Aa} \pm 335.30$ & $3.2629 \mathrm{Ab} \pm 0.1418$ \\
& Covered area without insects & $16.1 \mathrm{Ab} \pm 2.02$ & $1,216.76 \mathrm{Ab} \pm 308.26$ & $3.4816 \mathrm{Aa} \pm 0.1729$ \\
& Covered area with honeybees & $19.3 \mathrm{Ba} \pm 1.78$ & $1,816.61 \mathrm{Aa} \pm 289.35$ & $3.3204 \mathrm{Aab} \pm 0.1982$ \\
\hline \multirow{2}{*}{$06 / 25 / 11$} & Uncovered area & $18.7 \mathrm{Ab} \pm 1.74$ & $689.38 \mathrm{Ba} \pm 372.32$ & $2.5054 \mathrm{Ba} \pm 0.2366$ \\
& Covered area without insects & $15.1 \mathrm{Ac} \pm 1.31$ & $213.51 \mathrm{Bb} \pm 95.14$ & $2.4083 \mathrm{Ba} \pm 0.2390$ \\
& Covered area with honeybees & $20.7 \mathrm{Aa} \pm 1.22$ & $436.14 \mathrm{Ba} \pm 149.43$ & $2.4593 \mathrm{Ba} \pm 0.1586$ \\
\hline
\end{tabular}

Means in the same column followed by different lowercase letters differ between pollination tests on each sowing date according to the Student-Newman-Keuls test $(P<0.05)$. Means in the same column followed by different uppercase letters differ between sowing dates for each pollination test according to the $F$-test at the $5 \%$ significance level. ${ }^{a}$ Means calculated from eight observations. 
$P<0.0001$; cage with honeybees, $F=107.68, \mathrm{df}=$ $1, P<0.0001)$ (Table III).

There was no difference in the NGP between sowing dates in the uncovered area and the covered area without insects. However, a difference was observed in the NGP between sowing dates in the covered area with honeybees; an increased NGP was observed in the June 25th, 2011 plants compared with the May 25th, 2011 plants, regardless of the hybrid tested (NGP-sowing date: uncovered area, $F=2.86, \mathrm{df}=1, P=0.1005$; cage without honeybees, $F=3.58, \mathrm{df}=1, P=0.0671$; cage with honeybees, $F=7.33, \mathrm{df}=1, P=0.0107$ ) (Table III).

From the GY data, the value for the dependency of the rapeseed crop on Africanized honeybees ( $\left.D_{\text {rapeseed }}\right)$ was estimated for the two sowing dates, regardless of the hybrid tested, using the equation proposed by Robinson et al. (1989) as follows: $D_{\text {rapeseed }}=\left(Y_{o}-Y_{c}\right) / Y_{o}$, where $Y_{o}$ is the GY $\left(\mathrm{kg} \mathrm{ha}^{-1}\right)$ in the covered area with Africanized honeybees and $Y_{c}$ is the $\mathrm{GY}\left(\mathrm{kg} \mathrm{ha}^{-1}\right)$ in the covered area without insects. Therefore, $D_{\text {rapeseed }}=(1,816.61-1,216.76) / 1,816.61$ $=0.33$ in response to sowing on May 25th, 2011, and $D_{\text {rapeseed }}=(436.14-213.51) / 436.14=0.51$ in response to sowing on June 25th, 2011. Therefore, there was greater dependence on the presence of Africanized honeybees for the plants sown on June 25th, 2011.

The NPP for the Hyola 433 genotype in the uncovered area $(27.65 \%)$, covered area without insects $(59.98 \%)$ and covered area with honeybees (15.18\%) was greater than the NPP for the Hyola 61 hybrid, regardless of the sowing date (hybrid: uncovered area: $F=12.71, \mathrm{df}=1, P=0.0011$; cage without insects: $F=37.71$, df $=1, P<0.0001$; cage with honeybees: $F=4.70, P=0.0375$ ) (Fig. 4).

For the Hyola 61 hybrid, the NPP did not differ between the uncovered area and the covered area with honeybees, and the NPP values were greater than in the covered area without insects, regardless of the sowing date (pollination: Hyola $61, F=8.44$, $\mathrm{df}=2, P=0.0011)$. There was no difference in the
NPP among the pollination tests for the Hyola 433 genotype, regardless of the sowing date (pollination: Hyola 433: $F=0.003, \mathrm{df}=2, P=0.9968)$ (Fig. 4).

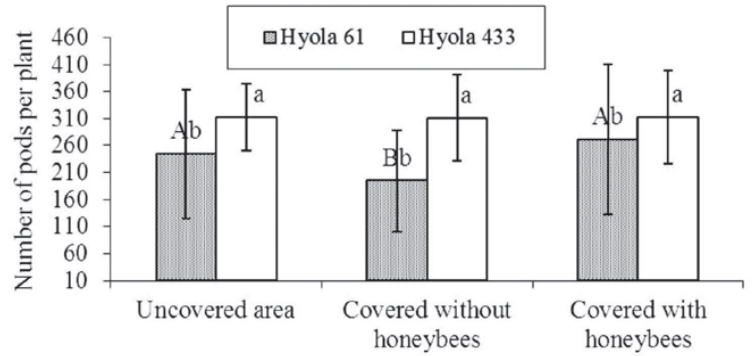

Fig. 4 - Number of pods per plant for each pollination test and hybrid regardless of the sowing date. Columns followed by different lowercase letters differ between hybrids for each pollination test according to the $F$-test $(P<0.05)$. Columns followed by different uppercase letters differ between pollination tests for each hybrid according to the StudentNewman-Keuls test $(P<0.05)$.

The Hyola 433 genotype exhibited a higher NGP and higher oil content (OC) than the Hyola 61 hybrid when sown on May 25th, 2011. For the June 25th, 2011 sowing date, the Hyola 433 hybrid exhibited a higher NPP and increased VG and GER compared with the Hyola 61 genotype. In contrast, the Hyola 61 hybrid exhibited a higher MTG than the Hyola 433 hybrid when sown on June 25th, 2011. There was no difference between the hybrids regarding the NPP, VG, GER and MTG when sown on May 25th, 2011 or the NGP and OC when sown on June 25th, 2011 (Table IV).

The Hyola 61 hybrid sown on May 25th, 2011 exhibited a higher NPP (160.07\%), OC (8.57\%), VG (5.49\%), GER (5.43\%) and MTG (29.86\%) compared with the hybrid sown on June 25th, 2011 (sowing date/Hyola 61: NPP: $F=185.12, \mathrm{df}=1$, $P<0.0001$; OC: $F=7.98$, df $=1, P=0.0080$; VG: $F=10.21, \mathrm{df}=1, P=0.0031 ;$ GER: $F=14.13$, $\mathrm{df}=1, P=0.0007$; and MTG: $F=128.79$, $\mathrm{df}=1$, $P<0.0001)$. In contrast, the Hyola 61 hybrid sown on June 25th, 2011 exhibited a higher NGP (5.88\%) compared with the hybrid sown on May 25th, 2011 (sowing date/Hyola 61: NGP: $F=9.34, \mathrm{df}=1$, $P=0.004)$ (Table IV). 
TABLE IV

$F$ probability values and means \pm standard deviation values for number of grains per pod (NGP), number of pods per plant (NPP), oil content (OC), vigor (VG), germination (GER) and mass of 1,000 grains (MTG) per rapeseed hybrid and sowing date combination in Marechal Cândido Rondon (state of Paraná, Brazil).

\begin{tabular}{|c|c|c|c|c|c|c|c|}
\hline \multirow[b]{2}{*}{ Hybrid } & \multirow[b]{2}{*}{ Sowing Date } & \multicolumn{6}{|c|}{ Variable $(\text { mean } \pm \mathrm{SD})^{a}$} \\
\hline & & NGP & NPP & $\mathrm{OC}(\%)$ & VG $(\%)$ & GER $(\%)$ & MTG $(\mathrm{g})$ \\
\hline $\mathrm{F}$ & & 41.79 & 3.19 & 13.03 & 0.10 & 0.03 & 0.11 \\
\hline$P$-value & & $<0.0001$ & 0.0833 & 0.0010 & 0.7513 & 0.8654 & 0.7449 \\
\hline Hyola 61 & $05 / 25 / 11$ & $\begin{array}{l}17 \mathrm{Bb} \\
\pm 2.09\end{array}$ & $\begin{array}{l}342 \mathrm{Aa} \\
\pm 65.45\end{array}$ & $\begin{array}{l}38 \mathrm{Ab} \\
\pm 3.42\end{array}$ & $\begin{array}{l}96 \mathrm{Aa} \\
\pm 2.68\end{array}$ & $\begin{array}{l}97 \mathrm{Aa} \\
\pm 2.56\end{array}$ & $\begin{array}{c}3.3438 \mathrm{Aa} \\
\pm 0.1836\end{array}$ \\
\hline Hyola 433 & & $\begin{array}{l}20 \mathrm{Aa} \\
\pm 2.03\end{array}$ & $\begin{array}{l}370 \mathrm{Aa} \\
\pm 47.61\end{array}$ & $\begin{array}{l}42 \mathrm{Aa} \\
\pm 1.85\end{array}$ & $\begin{array}{l}97 \mathrm{Aa} \\
\pm 2.02\end{array}$ & $\begin{array}{l}97 \mathrm{Aa} \\
\pm 1.54\end{array}$ & $\begin{array}{c}3.3661 \mathrm{Aa} \\
\pm 0.2038\end{array}$ \\
\hline $\mathrm{F}$ & & 0.13 & 62.55 & 0.50 & 10.90 & 13.28 & 11.99 \\
\hline$P$-value & & 0.7186 & $<0.0001$ & 0.4851 & 0.0023 & 0.0009 & 0.0015 \\
\hline Hyola 61 & $06 / 25 / 11$ & $\begin{array}{l}18 \mathrm{Aa} \\
\pm 2.64\end{array}$ & $\begin{array}{l}131 \mathrm{Bb} \\
\pm 27.52\end{array}$ & $\begin{array}{l}35 \mathrm{Ba} \\
\pm 1.97\end{array}$ & $\begin{array}{l}91 \mathrm{Bb} \\
\pm 4.46\end{array}$ & $\begin{array}{l}92 \mathrm{Bb} \\
\pm 4.72\end{array}$ & $\begin{array}{c}2.5750 \mathrm{Ba} \\
\pm 0.1725\end{array}$ \\
\hline Hyola 433 & & $\begin{array}{l}18 \mathrm{Ba} \\
\pm 2.97\end{array}$ & $\begin{array}{l}254 \mathrm{Ba} \\
\pm 39.75 \\
\end{array}$ & $\begin{array}{l}36 \mathrm{Ba} \\
\pm 2.54\end{array}$ & $\begin{array}{l}96 \mathrm{Aa} \\
\pm 4.63\end{array}$ & $\begin{array}{l}97 \mathrm{Aa} \\
\pm 4.09\end{array}$ & $\begin{array}{c}2.3403 \mathrm{Bb} \\
\pm 0.1778\end{array}$ \\
\hline
\end{tabular}

Means in the same column followed by different lower case letters differ between hybrids according to the $F$-test $(P<0.05)$ per sowing date. Means in the same column followed by different upper case letters differ between sowing dates according to the $F$-test $(P<0.05)$ for each hybrid. ${ }^{a}$ Means calculated from 12 observations.

The Hyola 433 genotype sown on May 25th, 2011 exhibited a higher NGP (11.11\%), NPP (45.67\%), OC (5.55\%) and MTG (43.83\%) than the hybrid sown on June 25th, 2011 (sowing date/ Hyola 433: NGP: $F=14.23$, df $=1, P=0.0006$; NPP: $F=56.0, \mathrm{df}=1, P<0.0001$; OC: $F=32.81$, df $=1, P<0.0001 ;$ MTG: $F=229.22$, df $=1, P<$ $0.0001)$. There was no effect of sowing date on the VG and GER for the Hyola 433 genotype (sowing date/Hyola 433: VG: $F=0.05, \mathrm{df}=1, P=0.8326$; GER: $F=0.08, \mathrm{df}=1, P=0.7776$ ) (Table IV).

\section{DISCUSSION}

Rapeseed is a predominantly self-pollinating species that produces a satisfactory GY in the absence of pollinating insects (Eisikowitch 1981, Mesquida et al. 1988, Mussury and Fernandez 2000, Hoyle et al. 2007).

Therefore, in this study, the hypothesis was that sufficient amounts of pollen grains deposited on the stigma of the same flower in the covered area without insects would result in GMP1, GMPd, NGP and GY values equivalent to the uncovered area and to the covered area with honeybees; however, this was not the case.

The data indicated that for the Hyola 61 hybrid sown on May 25th, 2011 in the uncovered area and in the covered area with honeybees, the GMP1 was $56.31 \%$ and $60.35 \%$ higher $(P<0.05)$ and the GMPd was $47.76 \%$ and $44.47 \%$ higher $(P<0.05)$, respectively, than in the covered area without insects. The Hyola 433 hybrid sown on May 25th, 2011 demonstrated a GMP1 that was $40.38 \%$ and $44.73 \%$ higher $(P<0.05)$ in the uncovered area and covered area with honeybees, respectively, than in the covered area without insects.

Furthermore, for the Hyola 61 genotype sown on June 25th, 2011, the GMPl was 25.64\% and $46.72 \%$ higher $(P<0.05)$ in the uncovered area and in the covered area with honeybees, respectively, than in the covered area without insects. For the Hyola 433 hybrid sown on June 25th, 2011, the GMPd was $83.67 \%$ and $77.96 \%$ higher $(P<0.05)$ in the uncovered area and covered area with honeybees, respectively, than in the covered area without insects. 
In the uncovered area and covered area with honeybees, the NGP was $21.73 \%$ and $19.86 \%$ higher $(P<0.05)$ and the GY was $46.16 \%$ and $49.30 \%$ higher $(P<0.05)$, respectively, than in the covered area without insects for the sowing date May 25th, 2011. The NGP was $10.76 \%$ and $37.09 \%$ higher $(P<0.05)$ in the covered area with honeybees compared with the uncovered area and the covered area without insects, respectively, for the sowing date June 25th, 2011. The GY was $222.90 \%$ and $104.27 \%$ higher $(P<0.05)$ in the uncovered area and covered area with honeybees, respectively, compared with the covered area without insects for sowing date June 25th, 2011.

Similar results were obtained in the B. napus crop pollinated by A. mellifera (Sabbahi et al. 2005, Abrol 2007, Araneda-Durán 2010, Rosa et al. 2011, Abrol and Shankar 2012).

It is likely that only self-pollination occurred in the covered area without insects. However, it is possible that the deposition of pollen on the stigma of the same flower was insufficient for the fertilization of all of the ovules, or the pollen did not come into contact with the stigma during the period when the stigma was receptive.

The lack of synchronization between stigma receptivity and viable pollen availability (DeGrandiHoffman and Chambers 2006), as well as the absence of fully-developed embryo sacs at the time of flower opening (Wang et al. 2009), are considered the main contributing factors for the lower production of seeds through self-pollination (DeGrandi-Hoffman and Chambers 2006).

Therefore, the data demonstrated that crosspollination by Africanized honeybees is efficient at increasing production rates in rapeseed crop.

The lack of a significant difference between the uncovered area and the covered area with honeybees for the yield components evaluated likely occurred because of the apiary containing six colonies of Africanized honeybees located approximately $1 \mathrm{~km}$ from the experimental area, as well as other potential pollinators non-Apis. The density of Africanized honeybees in the uncovered area because of the proximity of the apiary and the presence of other pollinators nonApis were sufficient to generate a production rate similar to that of the covered area with honeybees. In comparing two sowing dates May 25th, 2011 and June 25th, 2011, a larger proportional increase in GY was observed in the uncovered area and in the covered area with honeybees compared to the covered area without insects. Besides, the GY in the uncovered area was $157.98 \%$, was $469.88 \%$ in the covered area without insects, and was $316.52 \%$ greater in the covered area with honeybees for the sowing on May 25th, $2011(P<0.05)$ than to the sowing on June 25th, 2011 (Table III). This may have occurred because the climatic conditions for the June 25th, 2011 sowing date were more favorable for pollinators.

Pollination by honeybees depends on climatic conditions because these conditions affect both the crop and the honeybees (Abrol 2007). Africanized honeybees actively gather nectar at temperatures ranging between 15.48 and $31.09{ }^{\circ} \mathrm{C}$ and at a relative humidity between 43.13 and $92.70 \%$. For pollen, the optimal temperatures are between 15.48 and $27.61{ }^{\circ} \mathrm{C}$, and the optimal relative humidity is between 45.00 and $89.50 \%$ (Malerbo-Souza and Silva 2011).

In this study, the temperature was closer to the optimal ranges for Africanized honeybees during the second flowering period. Although the air temperature was higher during the flowering period for the hybrids sown on June 25th, 2011, the temperature was less ideal for the cultivation of rapeseed compared to the temperature recorded during the flowering period for the hybrids sown on May 25th, 2011; the entomophilous pollination mitigated, at least partially, the limitations in the GY, possibly because of the higher temperatures and lower rainfall observed in September of that year (Fig. 1). 
Despite the dependency values of 0.33 and 0.51 of the crop on Africanized A. mellifera on May 25th, 2011 and June 25th, 2011, respectively, under conditions more favorable to rapeseed development, such as on sowing date May 25th, 2011, rapeseed can exhibit a higher self-pollination rate, although the presence of Africanized honeybees significantly increased the crop production rates.

Almost all of the pollen produced in the anthers of rapeseed flowers is released shortly after the completion of flower opening (Mussury and Fernandez 2000, Abrol 2007), and high temperatures at anthesis can limit the growth of the pollen tube (Prasad et al. 2001, Kakani et al. 2005) and cause pollen degeneration (Nava et al. 2009), limiting the self-pollination process.

It is possible that the pollen produced and deposited on the stigma of the same flower was not intact because of the higher temperatures, limiting self-pollination during the second flowering period. This limitation in the fertilization of all of the ovules should have favored the cross-pollination process, therefore causing a greater dependency on honeybees for the crop, especially for sowing date June 25th, 2011.

However, although the hybrids sown on June 25th, 2011 demonstrated a greater dependency on honeybees, the GY for this period was significantly lower than for the hybrids sown on May 25th, 2011; therefore, planting at the end of June is not justified.

The analysis demonstrated that the interaction of hybrid $x$ sowing date was significant $(P<0.05)$ for all of the response variables, with the exception of GY (Table I), indicating that the hybrids responded differently to the time when sowing occurred. Both hybrids performed better when sown on May 25th, 2011 rather than on June 25th, 2011.

Yield and seed quality parameters tend to decrease when sowing is delayed after mid-April (Tomm et al. 2004). After anthesis, each $1{ }^{\circ} \mathrm{C}$ increase in temperature can trigger losses in GY of up to $289 \mathrm{~kg} \mathrm{ha}^{-1}$ (Si and Walton 2004).
When sown on May 25th, 2011, the Hyola 433 genotype exhibited an increased NGP (17.65\%) and an increased OC (10.52\%) compared with the Hyola 61 hybrid. For the sowing on June 25th, 2011, the Hyola 433 hybrid exhibited an increased NPP (93.89\%) and increased VG (5.49\%) and GER (5.43\%) compared with the Hyola 61 genotype (Table IV).

Sowing from late April to early June favors the performance of short-cycle genotypes, such as the Hyola 433 hybrid, compromising the yield in hybrids exhibiting medium and long cycles, such as Hyola 61 (Tomm et al. 2003), even though this latter hybrid may exhibit greater productivity under certain conditions (Tomm et al. 2010).

It is possible that the short-cycle Hyola 433 genotype suffered less because of the climatic conditions, especially the low rainfall in September, compared to the medium-cycle Hyola 61 hybrid (Fig. 1). Moreover, the Hyola 433 hybrid is suitable for soils with a high fertility (Tomm et al. 2009), a characteristic observed in the soils of the study area.

In addition, climatic conditions during the flowering period can influence nectar secretion during the day, which can vary depending on the cultivar (McGregor 1976, Free 1993, Delaplane and Mayer 2000). Cultivars less tolerant to heat can reduce the amount or concentration of secreted nectar as well as the pollen availability throughout the day, causing the flowers to become less attractive to pollinators in spite of an adequate insect density, limiting the cross-pollination process and leading to reduced production (Chambó et al. 2011).

There was no effect $(P>0.05)$ of pollination on the OC in seeds, VG, GER and MTG, suggesting that these variables were not affected by insect pollination (Table I).

No significant difference was observed among the areas available for visitation by insects and the covered areas with and without honeybees for the MTG values and seed vigor in Adesmia latifolia (Camacho 
and Franke 2008) and in the seed germination rate in Glycine max (Chiari et al. 2008). In contrast, in rapeseed (cv. OAC Triton), the presence of honeybees increased the seed germination from $83 \%$ to $96 \%$ (Kevan and Eisikovitch 1990).

Insects do not directly influence features related to the physiological quality of the seed because these features are related to the physiological factors of the plant itself and to the climatic conditions. However, in a number of situations, a direct influence may occur, causing an increase in these features (Camacho and Franke 2008, Chiari et al. 2011, Toledo et al. 2011).

The data demonstrated that the crosspollination process performed by Africanized $A$. mellifera improved the crop production rates in rapeseed. Productivity in the hybrids was increased in terms of the yield components for the May 25th, 2011 sowing date compared with the June 25th, 2011 sowing date. The hybrid yield loss may have been compensated, at least partially, by honeybee pollination when the temperature was higher and consequently less favorable to crop development, as observed for the June 25th, 2011 sowing date.

\section{ACKNOWLEDGMENTS}

To Bee Research Group - Universidade Estadual de Maringá for providing all cages pollination, equipment and materials. To Universidade Estadual do Oeste do Paraná for giving the experimental area. To Coordenação de Aperfeiçoamento de Pessoal de Nível Superior (CAPES) for financial support.

\section{RESUMO}

Neste estudo realizado no Oeste do Estado do Paraná, Brasil, dois híbridos de canola foram avaliados quanto aos componentes de produção de grãos e qualidade fisiológica de sementes, em três testes de polinização e duas épocas de semeadura. Os tratamentos foram constituídos pela combinação de dois híbridos de canola (Hyola 61 e Hyola 433), três testes de polinização (área descoberta, área coberta sem insetos e área coberta com abelhas africanizadas) e duas épocas de semeadura (25/05/2011 e 25/06/2011). A produção em canola pode ser aumentada em termos de seus componentes produtivos com a presença de abelhas africanizadas durante a floração. Os híbridos podem ter suas perdas produtivas atenuadas pela polinização cruzada realizada pelas abelhas africanizadas, especialmente quando as condições climáticas são menos propícias para o desenvolvimento da cultura de canola. A atividade de forrageamento das abelhas africanizadas pode ser limitada em decorrência dos fatores climáticos, ocasionando menor dependência da planta de canola aos potenciais polinizadores, em especial A. mellifera africanizada. Os híbridos de canola respondem diferentemente em relação à época de plantio, sendo o híbrido Hyola 433 de ciclo curto, o mais indicado quando a semeadura ocorre em condições ambientais menos propícias.

Palavras-chave: Apis mellifera, Brassicaceae, condições climáticas, polinizadores.

\section{REFERENCES}

ABROL DP. 2007. Honeybees and rapeseed: a pollinator-plant interaction. Adv Bot Res 45: 337-367.

ABROL DP. 2012. Pollination biology: biodiversity conservation and agricultural production. New York: Springer, $792 \mathrm{p}$.

ABrol DP AND Shankar U. 2012. Pollination in oil crops: recent advances and future strategies. In: GUPTA SK. (Ed), Technological innovations in major world oil crops, vol. 2, New York: Springer, New York, USA, p. 221-267.

AranedA-DurÁN XA, UlloA RB, CARrillo JA, CONTRERAS JL AND BASTIDAS MT. 2010. Evaluation of yield component traits of honeybee-pollinated (Apis mellifera L.) rapeseed canola (Brassica napus L.). Chil J Agric Res 70: 309-314.

Becker HC, DAmgaARD C AND KARLsSon B. 1992. Environmental variation for outcrossing rate in rapeseed (Brassica napus). Theor Appl Genet 84: 303-306.

BRASIL. 2009. MINISTÉRIO DA AGRICULTURA, PECUÁRIA E ABASTECIMENTO. Regras para análise de sementes. Brasília: SNDA/DNDV/CLAV, Brazil, 399 p.

CAMACHO JCB AND FRANKE LB. 2008. Efeito da polinização sobre a produção e qualidade de sementes de Adesmia latifolia. Rev Bras Sementes 30: 81-90.

CFIA - CAnadian Food Inspection Agency. 1999. The biology of Brassica napus. Ontario: Plant Biosafety Office, Canada, 20 p.

CHAMBó ED, GARCIA RC, OLIVEIRANTEAND DUARTE-JÚNIOR JB. 2011. Honey bee visitation to sunflower: effects on pollination and plant genotype. Sci Agric 68: 647-651. 
CHIARI WC, RUVOlO-TAKASUSUKI MCC, CHAMBÓ ED, ARIAS CA, HOFFMANN-CAMPO CB AND TOLEDO VAA. 2011. Gene flow between conventional and transgenic soybean pollinated by honeybees. In: HASANEEN MNAG (Ed), Herbicides: mechanisms and mode of action, Rijeka: InTech, Croatia, p. 137-152. Available at: http://www. intechopen.com/books/herbicides-mechanisms-andmode-of-action/gene-flow-between-conventional-andtransgenic-soybean-pollinated-by-honeybees. Accessed on: 6 June 2012.

Chiari WC, TOledo VAA, HofFMANN-CAMPo CB, RuvoloTAKASUSUKI MCC, TOLEDO TCSOA AND LOPES TS. 2008. Polinização por Apis mellifera em soja transgênica [Glycine $\max$ (L.) Merrill] Roundup Ready ${ }^{\mathrm{tm}}$ cv. BRS 245 RR e convencional cv. BRS 133. Rev Acta Sci Agron 30: 267-271.

ChIARI WC, TOLEDO VAAT, RUVUlo-TAKASUSUKI MCC, Oliveira AJB, SAKaguti ES, ATtencia VM, Costa FC AND Mitsui MH. 2005. Pollination of soybean (Glycine $\max$ L. Merril) by honeybees (Apis mellifera L.). Braz Arch Biol Technol 48: 31-36.

CONAB - COMPANHIA NACIONAL DE ABASTECIMENTO. 2012. Acompanhamento de safra brasileira: grãos, oitavo levantamento, maio 2012. Brasília: CONAB, Brasil, 34 p.

DEGRANDI-HofFMAN G AND CHAMBERS M. 2006. Effects of honey bee (Hymenoptera: Apidae) foraging on seed set in self-fertile sunflowers (Helianthus annuus L.). Environ Entomol 35: 1103-1108.

Delaplane KS AND MaYer DF. 2000. Crop pollination by bees. New York: CABI Publishing, New York, USA, 332 p.

EISIKOWITCH D. 1981. Some aspects of pollination of oil-seed rape (Brassica napus L.). J Agric Sci 96: 321-326.

EMBRAPA - EMPRESA BRASILEIRA DE PESQUISA AGROPECUÁRIA. 2006. Sistema brasileiro de classificação de solos, $2^{\mathrm{a}}$ ed., Rio de Janeiro: Embrapa solos, Brasil, 306 p.

FREE JB. 1993. Insect pollination of crops, $2^{\text {nd }}$ ed., London: Academic Press, 544 p.

Hoyle M, Hayter K AND CResswell JE. 2007. Effect of pollinator abundance on self-fertilization and gene flow: application to GM canola. Ecol Appl 17: 2123-2135.

KaKani VG, REDDY KR, Koti S, WALlace TP, PRASAD PVV, REDDY VRAND ZHAO D. 2005. Differences in in vitro pollen germination and pollen tube growth of cotton cultivars in response to high temperature. Ann Bot 96: 59-67.

KEVAN PG AND EIsIKOWITCH D. 1990. The effects of insect pollination on canola (Brassica napus L. cv. O.A.C. Triton) seed germination. Euphytica 45: 39-41.

Malerbo-SouZa DT AND Silva FAS. 2011. Comportamento forrageiro da abelha africanizada Apis mellifera L. no decorrer do ano. Acta Sci Anim Sci 33: 183-190.

MCGREGOR SE. 1976. Insect pollination of cultivated crop plants. Washington: Agricultural Research Service, USDA, 411 p.

Mesquida J, RenARD M AND PIERRE JS. 1988. Rapeseed (Brassica napus L.) productivity the effect of honeybees (Apis mellifera L.) and different pollination conditions in cage and field tests. Apidologie 19: 51-72.
MORANDIN LA AND WINSTON ML. 2005. Wild bee abundance and seed production in conventional, organic, and genetically modified canola. Ecol Appl 15: 871-881.

MORRISON MJ AND STEWART DW. 2002. Heat stress during flowering in Summer Brassica. Crop Sci 42: 797-803.

MUSSURY RM AND FERNANDES WD. 2000. Studies of the floral biology and reproductive system of Brassica napus L. (Cruciferae). Braz Arch Biol Technol 43: 111-117.

NAVA GA, MARODIN GAB AND SANTOS RP. 2009. Reprodução do pessegueiro: efeito genético, ambiental e de manejo das plantas. Rev Bras Frutic 31: 1218-1233.

OGTR - OfFICE OF THE Gene TeChNOLOGy Regulator. 2011. Biology of Brassica napus L. (Canola). Canberra: OGTR, Australia, $72 \mathrm{p}$.

Pierre J, VAissière B, VAlléE P AND Renard M. 2010. Efficiency of airborne pollen released by honeybee foraging on pollination in oilseed rape: a wind insect-assisted pollination. Apidologie 4: 109-115.

Prasad PVV, CRAUford PQ, KAKANI VG, WheElER TR AND BOOTE K. 2001. Influence of high temperature during preand post-anthesis stages of floral development on fruit-set and pollen germination in peanut. Aust J Plant Physiol 28: 233-240.

Robinson WS, NowogrodzKI R AND Morse RA. 1989. The value of honey-bees as pollinators of U.S. crops. Am Bee J 129: 411-423.

Rosa ADS, BLochteIn B AND LIMA DK. 2011. Honey bee contribution to canola pollination in Southern Brazil. Sci Agric 68: 255-259.

SABBAHI R, Oliveira D AND MARCEAU J. 2005. Influence of honey bee (Hymenoptera: Apidae) density on the production of canola (Cruciferae: Brassicacae). J Econ Entomol 98: 367-372.

SAS InSTITUTE. 2012. SAS/STAT user's guide, version 9.3. Cary: SAS Institute, USA.

Si P AND WALTON GH. 2004. Determinants of oil concentration and seed yield in canola and Indian mustard in the lower rainfall areas of Western Australia. Aust J Agric Res 55: 367-377.

Thomas P. 2003. Canola growers manual. Winnipeg: Canola Council of Canada, Canada. Available at: http://www. canolacouncil.org/crop-production/canola-grower'smanual-contents. Accessed on: 10 June 2012.

ThOMSON JD AND GoOdell K. 2002. Pollen removal and deposition by honeybee and bumblebee visitors to apple and almond flowers. J Appl Ecol 38: 1032-1044.

Toledo VAA, Chambó ED, Halak AL, Faquinello P, PARPINELLI RS, OSTROWSKI KR, CASAGRANDE APB AND RuVOLO-TAKASUSUKI MCC. 2011. Biologia floral e polinização em girassol (Helianthus annuus L.) por abelhas africanizadas Rev Sci Agrar Paraná 10: 5-17.

TOMm GO, Garrafa M, Benetti V, Wolbolt AA AND FIGER E. 2004. Efeito de épocas de semeadura sobre o desempenho de genótipos de canola em Três de Maio, RS. Passo Fundo: Embrapa Trigo, Brasil, 11 p. 
TOMM GO, MENDES MRP, FADONI AC AND CUNHA GR. 2010 Efeito de épocas de semeadura sobre o desempenho de genótipos de canola de ciclo precoce e médio, em Maringá, Paraná. Passo Fundo: Embrapa Trigo, Brasil, 13 p.

Tomm GO, Mendes MRP, Gomes JR, Buzza G, Swann B AND SMALlRidge B. 2003. Comportamento de genótipos de canola em Maringá em 2003. Passo Fundo: Embrapa Trigo, Brasil, 5 p.

TOMM GO, Wiethölter S, DALMAgo AA AND SANTOS HP. 2009. Tecnologia para produção de canola no Rio Grande do Sul. Passo Fundo: Embrapa Trigo, Brasil, 41 p.

USDA - United States DePARTMENT OF AgRiculture. 2012. World agricultural production. Washington: USDA, Available at: http://usda01.library.cornell.edu/usda/fas/ worldag-production//2010s/2011/worldagproduction-0511-2011.pdf. Accessed on: 30 January 2013.
WANG X, Mathieu A, COURNÈde PH, Allirand JM, JUlLIEN A, REFFYe P AND ZHANG BG. 2009. Stochastic models in floral biology and its application to the study of oilseed rape (Brassica napus L.) fertility. In: Li B, Guo Y and Jaeger M (Eds), Proceedings, Symposium: The Third International Symposium on Plant Growth Modeling, Simulation, Visualization and Applications (PMA 09), 9-13 November 2009, Beijing, China, p. 175-182.

Wilcock C AND NeIland R. 2002. Pollination failure in plants: why it happens and when it matters. Trends Plant Sci 7: 270-277.

WILliams IH, MARTIN AP AND WHITE RP. 1987. The effect of insect pollination on plant development and seed production in winter oil-seed rape (Brassica napus L.). J Agric Sci 109: 135-139. 